\title{
薬剤師に求められる新たな薬剤師業務に関する薬学生の意識調査
}

\author{
徳永 仁, ${ }^{*}$ 高村徳人，緒方賢次，吉田裕樹，瀬戸口奈央，佐藤圭創
}

\section{A Survey of Student Pharmacists' Attitudes toward New Procedures Expected for Future Pharmacists}

\author{
Jin Tokunaga, ${ }^{*}$ Norito Takamura, Kenji Ogata, Hiroki Yoshida, \\ Nao Setoguchi, and Keizo SATO \\ School of Pharmaceutical Sciences, Kyushu University of Health and Welfare, \\ 1714-1 Yoshino, Nobeoka, Miyazaki 882-8508, Japan
}

(Received September 10, 2009; Accepted March 5, 2010; Published online March 9, 2010)

\begin{abstract}
Bedsides conventional bedside training the Department of Pharmacy of Kyushu University of Health and Welfare covers advanced practices focused on new procedures expected for future pharmacists. A questionnaire survey was conducted among the 4th year students of the 6-year curriculum of the department in order to retrospectively evaluate their attitudes toward basic life support, and the necessity and feasibility of items related to the training. Sixty-nine percent of the students responded that they would provide appropriate treatment under a situation where basic life support was needed. The item regarded as most necessary and feasible before training was "treatment for basic life supportcardiopulmonary resuscitation." After training, however, "checking vital signs," "physical assessment," and "pharmacist's assistance in medication" were the items rated as equal to or higher than "treatment for basic life supportcardiopulmonary resuscitation." The lowest ranked item in terms of necessity and feasibility both before and after training was "intramuscular/subcutaneous injection," followed by "intravenous injection" and "normal intravenous collection of blood" in that order. The results of this attitude survey demonstrated that many students were willing to perform such operations as part of checking vital signs and physical assessment.
\end{abstract}

Key words_— vital sign; physical assessment; basic life support; cardiopulmonary resuscitation; bedside training; attitude survey

緒言

2007 年の医療法改正に伴って，薬局が「医療提 供施設」として位置づけられるなど薬剤師を取り巻 く環境は大きく変化してきている，また，日本病院 薬剤師会は薬剤師によるバイタルサインの確認など 職能拡大に関する議論を展開しており, ${ }^{1)}$ 薬科大学 に対しても新たな薬剤師業務につながる教育を要望 している. ${ }^{2}$

九州保健福祉大学薬学部ベッドサイド実習では, 2005 年度より今後の薬剤師に求められる新たな薬 剂師業務を見据えたアドバンスト実習を行ってい る、ベッドサイド実習では，注射剤調剤，注射剤の 混合やロールプレイ形式による注射剂処方せんの疑 義照会など基本的な薬剤師業務に加え，患者の存在

九州保健福祉大学薬学部

*e-mail: j-tokunaga@phoenix.ac.jp
を常に意識できる薬学系万能型実習人形，採血シミ ユレータ, フィジカルアセスメントモデル, 高機能 患者シミュレータなどを用いてバイタルサインの確 認法や一次救命救急法, さらに高村らが報告してい る薬学的分布診断法などを含めた新たに薬剤師業務 として求められる項目を行っている. ${ }^{3-8)}$ 薬学的分 布診断法とは，血清タンパク質上の薬物結合サイト の結合性をヒト血清アルブミン， $\alpha_{1}$-酸性糖タンパ ク質などの濃度を加味した上で評価する方法であ り, 従来の薬剂師業務にない薬学の研究成果（薬学 サイエンス）の組み込まれた技術である。これによ り，薬物の投与タイミングの設計や効果増強を設計 することが可能となる. ${ }^{9-11)}$ そこで，学生が実習を 通して今後の新たな薬剤師業務に関する意識がどの ように変化したのかを分析するために，学生の一次 救命救急に関する意識と実習関連項目の必要性と実 施可能性を回顧的に調査したので報告する. 


\section{方法}

1. ベッドサイド実習の概要 平成 21 年度 45 月に 4 年生 146 名 (6 年制課程 121 名 +4 年制課 程 25 名）を対象に初めての 6 年制課程におけるべ ッドサイド実習を実施した。1 サイクル 45-46人 (1 日の実習時間 : 約 5-6 時間, 実習期間 : 前期 5 日間）とし，3 サイクル（模擬病院薬局・模擬調剤 薬局とのローテーション), 5 名の担当教員で行つ た。各実習は前期 5 日間と後期 9 日間の 14 日間 （合計 42 日間）からなる。模擬病院薬局・模擬調剂 薬局では，調剤・製剤業務，リスクマネージメント に加え, 適切な OTC 薬の選択, 診療報酬の計算法 など基本的・実践的な薬剂師業務を指導してい る. ${ }^{12-17)}$ ベッドサイド実習の前期ではアドバンスト 実習を中心に，後期では空口・病棟業務において必 要とされる基本的薬剤師業務（情報提供・無菌操作 など）を指導する．バイタルサインを扱う項目（前 期 4 日目）のみ，本学薬学部医師 1 名の協力を得て いる。ベッドサイド実習で行っている実習内容を Table 1 に示した.

2. 一次救命救急に関する実態 ·意識調査 ベ ッドサイド実習終了後の学生 45 名（3 サイクル中 の 1 クール分, 6 年制課程 4 年生 37 名 +4 年制課程 4 年生 8 名）に対し，アンケート調査を行い，全員 から回収できた（回収率 $100 \%$ ）。この 1 クール分 の学生のグループ分けに関しては特別な配慮は行っ ておらず，特に救命救急に対して意識の高い学生が 集中している訳ではない。調査内容は，1過去にお ける一次救命救急の対処法の講義・演習の受講の有 無，(2)受講がある場合の場所・時期，(3)一次救命救 急を必要とする状況に遭遇した場合の行動の程度, (4)行わないと回答した場合の理由，である．各項目 は記名式で選択・記述形式とした。

\section{3. 実習関連項目に対する評価アンケート対} 象学生は「方法」2.と同じである。実習関連項目 の必要性と実施可能性について，実習前と実習終了 時点における評価として記名式にて回顧的に調査し た。アンケートは visual analog scale（VAS）法を 用いて評価を行った. ${ }^{18)}$ そのアンケート内容は, (1) バイタルサインの確認, (2)フィジカルアセスメント の確認，(3)薬剂師による服薬介助，(4)筋肉内注射・ 皮下注射，(5)静脈内注射，(6)穿刺採血（血糖值等の
Table 1. Contents of Bedside Training

\begin{tabular}{|c|c|}
\hline 投薬方法 & $\begin{array}{l}\text { オブラートと嚥下ゼリーの飲みやすさの評価 } \\
\text { ネブライザーを使用した薬液噴霧 } \\
\text { 薬学系万能型実習モデルへの坐剂・グリセリ } \\
\text { ン浣腸投与 } \\
\text { 样々な投与ルートの確認 (皮下・筋肉・静脈 } \\
\text { 注射, 中心静脈栄養法など) }\end{array}$ \\
\hline 注射剂業務 & $\begin{array}{l}\text { 注射剂の混合, 観察 } \\
\text { 配合変化について書籍, インタビューフォー } \\
\text { 等を用いた情報収集 } \\
\text { 注射剤の混注 }\end{array}$ \\
\hline 注射剂調剂 & $\begin{array}{l}\text { 注射処方箋に基づく個人別調剤・鑑査 } \\
\text { ロールプレイ形式による注射剂処方せんの医 } \\
\text { 師への疑義照会 } \\
\text { リスクマネネージメトをテーマとしたスモー } \\
\text { ルグループディスカッション }\end{array}$ \\
\hline & $\begin{array}{l}\text { 薬学系万能型実習人形に装着した皮下用パッ } \\
\text { 装着式上腕筋肉注射モデルへの筋肉内注射 } \\
\text { 採血静注シミュレータを用いた模擬血液採血 }\end{array}$ \\
\hline 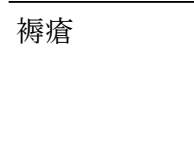 & $\begin{array}{l}\text { 裖瘡パットを用いたステージ別の薬剤選択・ } \\
\text { 袢瘡ケア } \\
\text { モイスチャーチェッカーを用いた肌の水分量 } \\
\text { の測定 }\end{array}$ \\
\hline 無菌操作* & 手洗いと手袋の着脱及び注射剂混合 \\
\hline 情報提供* & $\begin{array}{l}\text { 薬局での薬剂交付, 病棟での服薬指導 } \\
\text { 一般用医薬品の情報提供, 疑義照会 } \\
\text { 電子カルルからの患者情報の抽出 }\end{array}$ \\
\hline $\begin{array}{l}\text { バイタルサイ } \\
\text { ンの確認・救 } \\
\text { 命救急処置 }\end{array}$ & 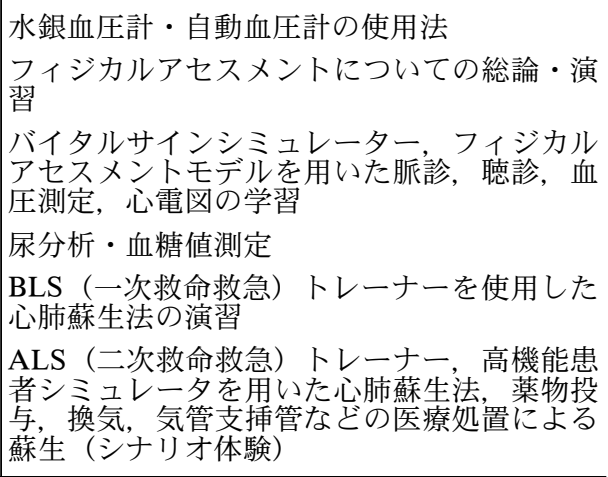 \\
\hline $\begin{array}{l}\text { 薬学的分布診 } \\
\text { 断法・その他 }\end{array}$ & $\begin{array}{l}\text { 血清タンパク結合の理解 } \\
\text { 薬学的分布診断法に基づく, リウマ設計 } \\
\text { 対するNSA患者に } \\
\text { フェイススケールを用いたロールプレイ } \\
\text { 薬剤師の技術を向上させる道具の考案 }\end{array}$ \\
\hline
\end{tabular}

*; 後期ベッドサイド実習では様々な状況を設定したロールプレイ形 式による学習法を予定している. 5 年次で選択する臨床薬学コースを専 攻した場合「病院薬学演習」において, さらなるアドバンスト的内容 を含む薬剤師業務について修得する。

測定など)，(7)通常の静脈内採血，8簡易測定キッ 卜を用いて病気の判定, (9)一次救命処置・心肺蘇生, (10)二次救命処置，である．これらの項目について， 薬剂師における必要性の程度と学生が薬剤師になっ 
た時の実施可能性の程度を記名式にて調査した。必 要性については，カラム右端を「薬剤師に必要であ る」，カラム左端を「全く必要でない」とし，実施 可能性については，カラム右端を「薬剤師になつた ら行いたい」，カラム左端を「全く行いたくない」 とした。 また，自分の必要性と実施可能性がどこに 位置するのかを学生に蛍光ペンで直線を引かせた。 ここで得られた必要性及び実施可能性のデー夕は, 枠全体の長さに対し蛍光ペンで引いた線の長さの割 合を 1 項目ずつ計算した後，パーセントで表した。

\section{4. 統計解析 各アンケート項目の必要性と実} 施可能性における実習前後の差に関しては，ウィル コクソンの符号付順位和検定（Wilcoxon signedrank test）を用い解析を行った.

結果

\section{1. 一次救命救急に関する実態・意識調査「べ} ッドサイド実習が始まるまでに AED の使用法や心 肺蘇生法などの一次救命救急の対処法の講義・演習 を受けたことがありますか」との問いに対して「あ る」が 64\%，「ない」が 36\%であった。「ある」と の回答において，どこで講義・演習を受けました か」との問いに対して，自動車学校が $78 \%$ ，高校 が $16 \%$, 中学が 6\%であった（複数回答可）.

次に，「目の前で家族，友達，一般市民が倒れた ら, 一次救命救急を行いますか」との問いに対し て，「意識の確認を行い，心肺蘇生，AED などの処 置をためらわず行う」は 4\%，「意識の確認を行い, 心肺蘇生，AED などの処置をためらいはあるもの の行う」は $65 \%$ ，「意識の確認をして，必要に応じ
て 119 番通報，助けを呼ぶで終える」は $31 \%$ ，「意 識の確認もせず，119 番通報のみで終える」は $0 \%$, 「何もしない」は $0 \%$ であた（Fig. 1)。「意識の確 認をして，必要に応じて 119 番通報，助けを呼ぶで 終える」の理由としては，「誤った心肺蘇生を行う かもしれないと不安がある」「自信がないから」「心 肺停止というわけではないから」などが挙げられた。

\section{2. 実習関連項目に対する評価 Table 2 は,} 実習関連項目に対する学生による必要性と実施可能 性を示している，実習前後における必要性と実施可 能性は，いずれの項目において有意な増加（ $p<$ 0.01）を示した。実習前における必要性と実施可能 性の最も高かった項目は「一次救命処置・心肺蘇生」 であった。しかしながら，実習後においては必要性 と実施可能性ともに「バイタルサインの確認」「フ イジカルアセスメントの確認」「薬剤師による服薬 介助」が「一次救命処置・心肺蘇生」と比較して同 等又は高かった。また，実習前後における必要性と 実施可能性の最も低かった項目は，順に「筋肉内注 射・皮下注射」「静脈内注射」「通常の静脈内採血」 であった。さらに，実習前における必要性と実施可 能性又は実習後における必要性と実施可能性では, いずれも有意差は認められなかった。しかしなが ら，実習後における実施可能性は必要性に比べて同 等又は低い傾向がみられた。

\section{考察}

学生の一次救命救急に関する意識調査を行つた結 果， $69 \%$ の学生は心肺蘇生・AED などの処置を行 うと回答し，また，学生が考える実習関連項目の必

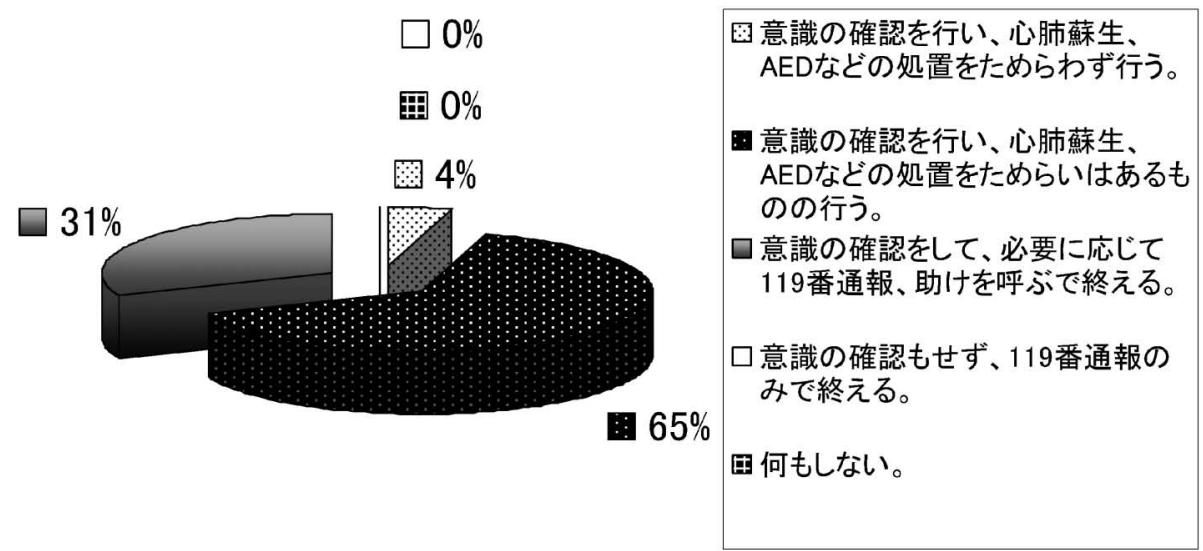

Fig. 1 Possibility of Students Providing Appropriate Treatment under a Situation Where Basic Life Support Is Needed 
Table 2. Change in the Rating of Necessity and Feasibility of Each Training Item on Comparison of Responses on Surveys Conducted before and after Bedside Training

\begin{tabular}{|c|c|c|c|c|}
\hline \multirow{2}{*}{$\begin{array}{c}\text { 実習関連項目 } \\
\text { の自己評 }\end{array}$} & \multicolumn{2}{|c|}{ 必要性（\%） } & \multicolumn{2}{|c|}{ 実施可能性（\%) } \\
\hline & 実習前 & 実習後 & 実習前 & 実習後 \\
\hline $\begin{array}{l}\text { バイタルサインの確 } \\
\text { 認 }\end{array}$ & $45 \pm 4.0$ & $84 \pm 2.7^{* *}$ & $41 \pm 4.7$ & $78 \pm 3.7^{* *}$ \\
\hline $\begin{array}{l}\text { フィジカルアセスメ } \\
\text { ントの確認 }\end{array}$ & $41 \pm 3.9$ & $78 \pm 3.3^{* *}$ & $39 \pm 4.3$ & $74 \pm 3.9^{* *}$ \\
\hline $\begin{array}{l}\text { 薬剂師による服薬介 } \\
\text { 助 }\end{array}$ & $48 \pm 4.4$ & $78 \pm 3.6^{* *}$ & $47 \pm 4.9$ & $78 \pm 3.8^{* *}$ \\
\hline $\begin{array}{l}\text { 筋肉内注射・皮下注 } \\
\text { 射 }\end{array}$ & $18 \pm 2.7$ & $49 \pm 4.1^{* *}$ & $21 \pm 3.1$ & $47 \pm 4.6^{* *}$ \\
\hline 静脈内注射 & $21 \pm 3.1$ & $50 \pm 4.2^{* *}$ & $22 \pm 3.5$ & $48 \pm 4.9^{* *}$ \\
\hline $\begin{array}{l}\text { 穿刺採血（例えば血 } \\
\text { 糖値等の測定など） } \\
\end{array}$ & $30 \pm 3.2$ & $61 \pm 4.2^{* *}$ & $30 \pm 3.9$ & $58 \pm 4.4^{* *}$ \\
\hline 通常の静脈内採血 & $22 \pm 2.9$ & $51 \pm 4.3^{* *}$ & $24 \pm 3.5$ & $51 \pm 4.9^{* *}$ \\
\hline $\begin{array}{l}\text { 簡易測定キットを用 } \\
\text { いて病気の判定 }\end{array}$ & $36 \pm 4.2$ & $64 \pm 4.1^{* *}$ & $35 \pm 4.2$ & $61 \pm 4.3^{* *}$ \\
\hline $\begin{array}{l}\text { 一次救命処置・ 心肺 } \\
\text { 蘇生 }\end{array}$ & $51 \pm 4.3$ & $78 \pm 3.1^{* *}$ & $47 \pm 4.6$ & $74 \pm 4.1^{* *}$ \\
\hline 二次救命処置 & $33 \pm 3.7$ & $61 \pm 4.5^{* *}$ & $36 \pm 4.2$ & $59 \pm 4.7^{* *}$ \\
\hline
\end{tabular}

Values are the mean \pm S.E. $(n=45)$. ${ }^{* *}, p<0.01$ (Wilcoxon $t$-test).

要性と実施可能性を回顧的に調查した結果，実習前 後における必要性と実施可能性は，いずれの項目に おいて有意な増加（ $p<0.01 ）$ を示した。しかしな がら，項目によっては必要性と実施可能性ともに 50\%にも満たないものがあった.

「ベッドサイド実習が始まるまでに AED の使用 法や心肺蘇生法などの一次救命救急の対処法の講 義・演習を受けたことがありますか」との問いに対

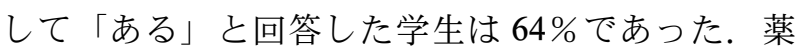
学部 1 年生を対象に救命救急教育を導入している酒 井らの調査では，79\%の学生が受講経験ありと報告 している. ${ }^{19)}$ よって, 薬学生の半数以上は一次救命 救急の対処法の講義・演習の受講経験はあると思わ れるが，これらの内容については繰り返し学ぶ必要 がある. ${ }^{20,21)}$ 以上のことから，薬学部における実 習・演習は一次救命救急の対処法の再確認・定着に つながると考えられるために必須なものであると考 える. また， 69\%の学生が目の前で倒れた者に対し て一次救命救急を行うと回答しているが，そのうち 「ためらわず行う」と回答した学生は $4 \%$ と非常に 少なかつた. 2004 年より一般市民による AED の使 用が許可されている現在，医療人養成を目指す薬学
部では，一般市民にも正しい一次救命救急を指導で きる薬剤師，つまり，社会に貢献できる薬剤師を育 成して輩出しなければならない，今後，ためらわず 一次救命救急が行えるように，さらに一般市民にも 指導ができるように，高学年においても繰り返し指 導を行う必要があると考える。この繰り返し指導 が，学生の「誤った心肺蘇生を行うかもしれないと 不安がある」「自信がないから」「心肺停止というわ けではないから」などの不安を軽減できると考えて いる。ベッドサイド実習では 4 年次のベッドサイド 実習後期，さらに 5 年次の病院薬学演習においても 一次救命救急の対処法について扱う予定である.

実習前における必要性と実施可能性の最も高かつ た項目は「一次救命処置・心肺蘇生」であったにも かかわらず，実習後においては「バイタルサインの 確認」「フィジカルアセスメントの確認」「薬剤師に よる服薬介助」が同等又は高くなった，学生は，べ ッドサイド実習を通して「バイタルサインの確認」 「フィジカルアセスメントの確認」は薬剤師として の業務の前に医療人としての必須な業務であると考 え，一般市民でもできる「一次救命処置・心肺蘇生」 と比較し同等又は高くなったのではないかと推察す る。「薬剤師による服薬介助」は，様々な投与ルー 卜の確認や服薬体験などから薬を飲む困難さを学 び，服薬を助けるという意識が芽生えたのでなない かと考えている．よって，「バイタルサインの確認」 「フィジカルアセスメントの確認」「薬剤師による服 薬介助」は，医療人として積極的に必要であり実施 を行うべきであるとの薬学生としての意識の現れで はないかと分析する．われわれは，バイタルサイン の数值を理解することと薬剂師自らが確認すること の違いは，患者との距離であると考えている．患者 に触れて，自ら確認することで患者との距離が縮ま り, 患者の薬剂師への期待感, 薬剂師の患者への責 任感が増し，それが薬剤師の技術を高める原動力に なると考える。

また，実習前後における必要性と実施可能性の最 も低かった項目が「筋肉内注射・皮下注射」「静脈 内注射」「通常の静脈内採血」であった理由は，学 生は侵襲的な行為に対して戸惑い・不安があるので はないかと考えている，さらに，実習後における実 施可能性は必要性に比べて同等又は低い傾向がみら れた理由としては，各々の項目について必要である 
とは思いながらも実施することには躊躇している現 れではないかと推察する。これらの内容に関しては 現段階では薬剤師としては行うことができない行為 ではあるが，これらの行為の背景には薬学的に重要 なポイントが多く存在するために，ベッドサイド実 習においても取り扱っている。重要なポイントと は，消毒方法，採血時間や適切な採血管の選択など についてである。もちろん，これらの医師・看護師 の行為を体験することにより職能体験にもつながる と考えている．薬学生の「筋肉内注射・皮下注射」 「静脈内注射」「通常の静脈内採血」の必要性と実施 可能性ともに $50 \%$ 前後の值が得られたことは，非 常に興味ある意識結果である。

日本病院薬剂師会の「新しい業務展開に向けた特 別委員会」では，医師の同意の下で，従来の薬剤師 業務にとらわれず積極的に行われている新たな業務 に関する実態調査を実施している. ${ }^{22,23)}$ その結果, 副作用予測又は回避に必要な血圧，脈拍，体温の測 定や聴診，視診などのフィジカルアセスメントは $4.5 \%$ 施設で行われており，「添付文書に記載され ている血液検査，心電図，胸部 X 線，TDM，尿検 査などの検査オーダー」も $4.2 \%$ の施設で行れてい ることが明らかになった。 よって，われわれが調査 した実習関連項目である「バイタルサインの確認」 「フィジカルアセスメントの確認」などは，既に複 数の施設において実施されている項目であることが 明らかになった。われわれはこれまでに病院薬剤師 を対象にしたアンケート調査において，薬剤師のバ イタルサインの確認, 救命救急教育さらに薬剂師の 業務拡大への関心度が高いことを報告してきてい る. ${ }^{24,25)}$ また，濃沼らは創造的な病院薬剂師業務の 方向性についてアンケート調査を実施しており，薬 剂師の 10 年後の将来展望としての採血や注射の実 施は，現段階では比較的肯定的に捉えている薬剤師 が多いことを報告している26)。さらに，看護師を対 象にアンケート調査を実施した結果，看護師が薬剂 師に望む業務として治療の質的向上の観点から TDM 時の採血などが挙げられたと報告してい

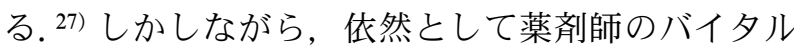
サインの確認やフィジカルアセスメントの導入に関 して様々な意見があるのは事実である. ${ }^{28)}$ まずは, 薬剤師同士の見解を一致させることが極めて重要な 課題であろう。その後，医師，看護師を始めとする
医療従事者，又は法律家，そして国民にも周知して もらう必要がある。

2012 年 3 月には 6 年制課程を修了した新しい薬 剂師が誕生する。今回のこれらの学生を含む意識調 査から, 学生は今後の薬剤師業務展開に関して非常 に前向きであり，バイタルサインの確認やフィジカ ルアセスメントなどを実施していきたいという学生 が多いことが明らかになった．従来とは明らかに異 なるカリキュラムで育成された薬剤師は，従来とは 異なる職能を持ち，新しい職域で活躍するであろ う。つまり，これは現薬剂師もバイタルサインの確 認やフィジカルアセスメントのスキルが要求される ことを意味する，よって，薬科大学は，薬学生だけ ではなく現薬剤師を対象にした生涯教育研修会など も展開する必要があり, ${ }^{2}$ また現薬剤師には新しい 薬剂師業務に関する議論，実施の上での見解の一致 が求められる。

本論文の一部は第 71 回九州山口薬学大会 $(2009$, 別府）において発表した.

本研究の一部は，質の高い医療人を養成する教育 プログラム（医療人 GP）「地域医療等社会的ニー ズに対応した質の高い医療人養成推進プログラム」 （文部科学省）の助成を受けた.

\section{REFERENCES}

1) The Yakuji Nippo, No. 10561, 1, July 30, 2008.

2) The Yakuji Nippo, No. 10537, 1, June 4, 2008.

3) Tokunaga J., Takamura N., Furuya Y. Motoya T., Hirai M., Nagata M., Kawachi A., Suzuki A., Matsuoka T., Jpn. J. Pharm. Health Care Sci., 33, 172-180 (2007).

4) Takamura N., Tokunaga J., Yakuzaigaku, 67, 165-171 (2007).

5) Tokunaga J., Takamura N., Ogata K., Yoshida H., Furuya Y., Totoribe K., Matsuoka T., Ono S., Jpn. J. Pharm. Health Care Sci., 34, 685-690 (2008).

6) Tokunaga J., Takamura N., Ogata K., Yoshida H., Totoribe K., Nagata M., Hidaka M., Matsuoka T., Ono S., Arimori K., Yakugaku Zasshi, 128, 1045-1055 (2008).

7) Tokunaga J., Takamura N., Ogata K., Yoshida H., Furuya Y., Totoribe K., Nagata M., Hidaka M., Matsuoka T., Ono S., Yamamoto 
R., Arimori K., Jpn. J. Pharm. Health Care Sci., 34, 847-852 (2008).

8) Tokunaga J., Takamura N., Ogata K., Yoshida H., Nagata M., Ono S., Yamamoto R., Arimori K., J. Jpn. Soc. Hosp. Pharm., 45, 793-797 (2009)

9) Takamura N., Tokunaga J., Arimori K., Yakugaku Zasshi, 127, 231-236 (2007).

10) Takamura N., Tokunaga J., Chosa E., Kawai K., Arimori K, Ooi K., Medicine and Drug Journal, 43, 963-973 (2007).

11) Takamura N., Tokunaga J., Chosa E., Kawai K., Fujita K., Arimori K., Yakugaku Zasshi, 127, 1805-1811 (2007).

12) Hirai M., Suzuki A., Majima T., Sakata A., Motoya T., Kawachi A., Shibata Y., Furuya Y., Tokunaga J., Takamura N., Jpn. J. Pharm. Health Care Sci., 34, 559-566 (2008).

13) Kawachi A., Shibata Y., Motoya T., Jpn. J. Pharm. Health Care Sci., 34, 474-480 (2008).

14) Shibata Y., Kawachi A., Takamura N., Tokunaga J., Furuya Y., Hirai M., Suzuki A., Majima T., Motoya T., J. Jpn. Pharm. Assoc., 60, 939-942 (2008).

15) Shibata Y., Kawachi A., Haramaki Y., Motoya T., Jpn. J. Pharm. Health Care Sci., 35, 11-17 (2009).

16) Shibata Y., Kawachi A., Motoya T., Jpn. J. Pharm. Health Care Sci., 35, 64-69 (2009).

17) Shibata Y., Kawachi A., Motoya T., Jpn. J. Pharm. Health Care Sci., 35, 259-266 (2009).
18) Naruhashi K., Nomura M., Kamei H., Ono S., Matsushita R., Shimizu S., Yokogawa K., Yamada K., Suzuki N., Miyamoto K., Kimura K., Yakugaku Zasshi, 123, 973-980 (2003) .

19) Sakai E., Teramachi H., Nishida H., Adachi T., Yakugaku Zasshi, 128, 1227-1233 (2008) .

20) Moser D. K, Coleman S., Heart Lung, 21, 372 -380 (1992).

21) Sugimoto H., Hiraide A., "BLS: Shasin to Douga de Wakaru Ichijikyumeishochi," ed. by Osaka Life Support Association, Gakken Co., Ltd., Tokyo, 2007, pp. 130-133.

22) The Yakuji Nippo, No. 10715, 1, July 31, 2009.

23) The Yakuji Nippo, No. 10722, 3, August 19, 2009.

24） Tokunaga J., Takamura N., Ogata K., Yoshida H., Yamamoto R., Jpn. J. Pharm. Health Care Sci., 35, 50-56 (2009) .

25) Tokunaga J., Koinuma M., Takamura N., Ogata K., Yoshida H., Yamamoto R., Nakamura H., Jpn. J. Pharm. Health Care Sci., 35, 417-422 (2009).

26) Koinuma M., Imai Y., Kanda M., Koike K., Miyazaki Y., Sato T., Nakamura H., Yakugaku Zasshi, 129, 887-896 (2009) .

27) Koinuma M., Hoshino S., Koike K., Nakamura H., Jpn. J. Soc. Pharm., 27, 17-26 (2009).

28) The Yakuji Nippo, No. 10752, 5, November 2, 2009. 